The FASEB Journal express article 10.1096/fj.02-0392fje. Published online October 18, 2002.

\title{
Degradation of cellular mRNA is a general early apoptosis- induced event
}

\author{
M. Julieta del Prete, ${ }^{*}$ Maria S. Robles, * Ana Guío, ${ }^{*}$ Carlos Martínez-A., ${ }^{*}$ Manuel Izquierdo,,$\dagger$ \\ and Jose A. Garcia-Sanz* \\ *Department of Immunology and Oncology, Centro Nacional de Biotecnología (CNB-CSIC), \\ Campus de Cantoblanco de la UAM, E-28049 Madrid, Spain, and Instituto de Biología y \\ Genética Molecular (IBGM-CSIC), Facultad de Medicina Universidad de Valladolid, Ramón y \\ Cajal 7, E-47005 Valladolid, Spain
}

Corresponding author: Jose A. Garcia-Sanz, Department of Immunology and Oncology, Centro Nacional de Biotecnología (CNB-CSIC), Campus de Cantoblanco de la UAM, E-28049 Madrid, Spain. E-mail: jasanz@cnb.uam.es

Present address for Ana Guío: Escuela Técnica Superior de Ingenieros Agrónomos, Universidad Politécnica de Madrid, Madrid, Spain.

\section{ABSTRACT}

The fate of cellular mRNAs was analyzed in several cell lines of lymphoid origin, after induction of apoptosis by different mechanisms. Cytoplasmic mRNAs are specifically degraded as part of the early apoptotic response. This degradation is not species restricted and is independent of the cell line, the apoptotic stimulus, the intrinsic half-life of the mRNAs, and the transcriptional status of the gene (constitutive or inducible). mRNA degradation precedes DNA fragmentation and correlates with the appearance of phosphatidylserine in the outer cell membrane. In addition, apoptosis-induced mRNA degradation is an active process that can be dissected from other apoptotic hallmarks (degradation of annexin V, DNA, and poly(ADP-ribose) polymerase [PARP]), which suggests that apoptosis-induced mRNA degradation is controlled by a distinct signaling pathway. Furthermore, mRNA degradation also occurs in vivo, specifically during thymocyte apoptosis. Taken together, these data support the notion that degradation of mRNA is a general early apoptotic event that may become a new apoptotic hallmark.

Key words: RNA metabolism • caspase inhibitors • signaling pathways $\bullet$ in vivo apoptosis

The genetically programmed cell death process known as apoptosis is fundamental for the normal development and homeostasis of tissues and organs in multicellular organisms.

The relevance of apoptosis is demonstrated both by the evolutionary conservation of basic steps in the corresponding pathways (1) and by the causal implication of aberrant apoptotic mechanisms in diseases including neurodegenerative diseases, ischemic damage, autoimmune disorders, and several forms of cancer (2-6). Apoptosis was originally characterized by morphological features such as membrane blebbing, cell shrinkage, formation of apoptotic bodies, chromatin condensation, nucleolus loss, and chromatin fragmentation into single or 
multiple nucleosomes $(7,8)$. In recent years, many molecules participating in the pathways mediating apoptosis have been identified (9). Caspase activation is a feature common to most of these pathways and leads to proteolytic cleavage of specific cell substrates (10-12), including poly(ADP-ribose) polymerase (PARP), lamins, histone H1 (13), and DNA protein kinase (14, 15), as well as proteins involved in cell growth, survival, and death (11). Caspases also cleave the inhibitor of caspase-dependent DNase (ICAD), thus releasing active caspase-dependent DNase (CAD), which after translocation to the nucleus fragments chromatin (16). In addition, several reports have analyzed the fate of RNA during apoptosis. Indeed, $\left[{ }^{3} \mathrm{H}\right]$ uridine pulse-chase experiments detected a twofold increase in RNA degradation rates in rat thymocytes after glucocorticoid treatment (17). More recently, cleavage of both 28S ribosomal RNA (rRNA) and Ro ribonucleoprotein-associated Y RNAs during apoptosis was shown $(18,19)$, but nothing is known regarding the fate of cytoplasmic mRNAs.

In the immune system, apoptosis plays a key role both in the control of lymphocyte maturation and in the maintenance of homeostasis of mature cell populations. During maturation, thymocytes undergo positive and negative selection, so that only about $5 \%$ successfully complete maturation and leave the thymus, and the large majority of immature cells die by apoptosis $(20,21)$. In addition, during an immune response, mature $\mathrm{T}$ cells of the appropriate antigenic specificity undergo clonal expansion and acquire effector functions, leading to antigen elimination. After antigen removal, the majority of expanded $\mathrm{T}$ cells must be eliminated to maintain homeostasis, while a small fraction of the $\mathrm{T}$ cell population remains as long-lasting memory cells. Apoptosis induced either by death receptor triggering or by growth factor deprivation has been implicated in the elimination of the majority of these clonally expanded $\mathrm{T}$ cells $(22,23)$. T-cell receptor (TCR) cross-linking leads to activation of resting T cells, whereas it induces apoptosis (activation-induced cell death [AICD]) in activated T cells (24). AICD has also been implicated in apoptosis during thymocyte development (25) and in the depletion of autoreactive $\mathrm{T}$ cells $(24,26)$. Furthermore, growth factor deprivation-induced apoptosis is independent of Fas-mediated signaling pathways, because patients with autoimmune lymphoproliferative syndrome have $\operatorname{AICD}$ defects $(27,28)$ despite normal growth factor deprivation-induced apoptosis (29).

The fate of cytoplasmic mRNAs was analyzed after triggering of apoptosis by direct crosslinking of the death receptor $\mathrm{CD} 95$, AICD, or growth factor deprivation. These experiments demonstrated that mRNA degradation is a general early apoptotic event taking place in all the analyzed cell lines, and also during in vivo physiological situations. Apoptosis-induced mRNA degradation is independent of the stimulus used, precedes DNA fragmentation, and is an active process that can be dissected from DNA fragmentation, PARP processing, and annexin V binding by the use of caspase inhibitors. These data suggest that a distinct signaling pathway, induced by death receptor triggering, is responsible for mRNA degradation during apoptosis. 


\section{MATERIALS AND METHODS}

\section{Cell lines, culture conditions, and reagents}

A20 (ATCC No. TIB208) is a mature murine (BALB/c) B cell line (30) (provided by Dr. Brás). CTLL-2 (ATCC No. TIB214) is a mouse cytotoxic T-cell clone requiring exogenous interleukin 2 (IL-2) for growth (31) (a gift from Dr. Erard). J-HM1-2.2 cells (hereafter referred to as JHM12) is a Jurkat derivative constitutively expressing the human muscarinic type I receptor (HM1R) (32) (provided by Dr. Weiss). JHM12-p35 was derived from JHM12 cells after the cDNA coding for the Autographa californica p35 gene was stably transfected under the control of the EF1 $\alpha$ promoter. Transfectants were selected by five rounds of treatment with anti-CD95 monoclonal antibody (mAb) $(50 \mathrm{ng} / \mathrm{ml}, 48 \mathrm{~h})$. Molt-4 (ATCC No. CRL-1582) is a human acute lymphoblastic leukemia cell line, which undergoes apoptosis after treatment with $316 \mathrm{nM}$ okadaic acid (33). All cells were cultured in IMDM-10 (Iscove's modified Dulbecco's medium containing 10\% heat-inactivated FCS, $10 \mathrm{mM}$ 4-(2-hydroxyethyl)-piperazine-1-ethanesulfonic acid [HEPES] $\mathrm{pH} 7.0,0.05 \mathrm{mM} \beta$-mercaptoethanol, and $2 \mathrm{mM}$ glutamine). CTLL-2 cells were supplemented with saturating concentrations of mouse rIL-2 (34).

AICD was induced in JHM12 cells $\left(10^{6}\right.$ cells $\left./ \mathrm{ml}\right)$ by activation with $500 \mu \mathrm{M}$ carbachol (Sigma, St. Louis, MO) (35) or plate-coated $10 \mu \mathrm{g} / \mathrm{ml}$ anti-CD3 $\varepsilon \mathrm{mAb}$ (T3b). For direct CD95 triggering of A20 or JHM12, these cells were treated with $50 \mathrm{ng} / \mathrm{ml} \mathrm{Jo} 2 \mathrm{mAb}$ (PharMingen, San Diego, $\mathrm{CA}$ ) or CH-11 mAb (Upstate Biotechnology, Lake Placid, NY), respectively. For mRNA halflife measurements, JHM12 cells were treated with carbachol $(500 \mu \mathrm{M}, 1 \mathrm{~h})$ before addition of 5 $\mu \mathrm{M}$ actinomycin D; this concentration of actinomycin D inhibits more than $90 \%$ of $\left[{ }^{3} \mathrm{H}\right] \mathrm{UTP}$ incorporation into trichloroacetic acid precipitable counts (not shown). Apoptosis caused by growth factor deprivation was induced in exponentially growing CTLL-2 cells after cells were washed three times in fresh IMDM-10 medium and were then resuspended at $0.5 \times 10^{6} \mathrm{cells} / \mathrm{ml}$ in fresh IMDM-10 devoid of IL-2. The irreversible and cell-permeable caspase inhibitor ZVAD-fmk (Z-Val-Ala-Dl-Asp fluoromethylketone; No. N1510; Bachem, Bubendorf, Switzerland) was added at a final concentration of $100 \mu \mathrm{M}$ at the specified times.

\section{Antigen-induced thymocyte apoptosis}

T-cell receptor $\mathrm{V} \alpha_{4} \mathrm{~V} \beta_{11}$ double transgenic mice (F5-TCR, provided by Dr. Kioussis) recognize the influenza virus A nucleoprotein peptide (NP-366-374) in the H2-D ${ }^{b}$ context (36). Intraperitoneal injection of antigenic peptide $\mathrm{NH}_{2}$-ASNENMDAM-COOH (Isogen, Maarssen, The Netherlands) in $200 \mu \mathrm{l}$ of PBS (9-75 nmol) leads to antigen-induced apoptosis of immature thymocytes $\left(\mathrm{CD}^{+} \mathrm{CD}^{+}\right.$cells are affected). Ninety minutes after injection, animals were killed by cervical dislocation, single thymocyte cell suspensions were obtained and minced through a $150-\mu \mathrm{m}$ nylon mesh, and aliquots were used for analysis of 1) thymocyte subpopulations after staining with CD4 and CD8 mAb $\left(1 \times 10^{6}\right.$ cells $\left.), 2\right)$ genomic DNA fragmentation $\left(20 \times 10^{6}\right.$ cells), 3) PARP processing $\left(5 \times 10^{6}\right.$ cells $)$, and 4) RNA preparation of thymocytes $\left(20 \times 10^{6}\right.$ cells) alone or mixed with $5 \times 10^{6}$ JHM12 cells.

\section{Cytofluorometric analysis}


After induction of apoptosis, annexin $\mathrm{V}$ binding to phosphatidylserine exposed on the outer surface of the membrane was measured by flow cytometry with fluorescein isothiocyanate (FITC)-labeled annexin V (Immunotech, Marseille, France). For cell cycle analysis, cells were permeabilized, were stained with propidium iodide (DNA-Prep Reagents Kit, Beckman Coulter, Miami, FL), and, after RNA digestion $\left(30 \mathrm{~min}, 37^{\circ} \mathrm{C}\right)$, were analyzed by flow cytometry to determine the fraction of surviving cells $\left(\mathrm{G}_{0} / \mathrm{G}_{1}, \mathrm{~S}\right.$, and $\mathrm{M}$ phases of the cell cycle) and nonviable cells (sub- $\mathrm{G}_{0} / \mathrm{G}_{1}$ phase). Cell suspensions from the thymus were stained with saturating concentrations of anti-CD4-FITC $\mathrm{mAb}$ and anti-CD8-phyco mAb (PharMingen) and were evaluated by multiparameter analysis.

\section{Western blot analysis}

Cytosolic cell extracts were prepared by incubation $\left(30 \mathrm{~min}, 4^{\circ} \mathrm{C}\right)$ in extraction buffer $(50 \mathrm{mM}$ Tris- $\mathrm{HCl} \mathrm{pH}$ 7.6, $150 \mathrm{mM} \mathrm{NaCl}, 0.5 \mathrm{mM}$ EDTA, 1\% Nonidet-P40, $1 \mathrm{mM}$ phenylmethylsulfonyl fluoride, $10 \mu \mathrm{g} / \mathrm{ml}$ aprotinin, $10 \mu \mathrm{g} / \mathrm{ml}$ leupeptin, and $1 \mu \mathrm{g} / \mathrm{ml}$ pepstatin), followed by high-speed centrifugation of lysates. Cytosolic extracts $(30 \mu \mathrm{g} / \mathrm{lane})$ were resolved by $8 \%$ sodium dodecyl sulfate-polyacrylamide gel electrophoresis and transferred to nitrocellulose membranes (BioRad, Hercules, CA). Western blots were performed with an anti-human PARP mAb, which recognizes mouse and human PARP (Labgen, Oxford, UK; 1:750 dilution), followed by horseradish peroxidase-conjugated anti-mouse IgG (Dako, Glostrup, Denmark), and blots were developed by enhanced chemiluminescence (Amersham Pharmacia Biotech, Uppsala, Sweden).

\section{RNA preparation and analysis}

Cytoplasmic RNA was prepared by using the NP40 method (37); thymocyte total RNA was prepared by the guanidinium-thiocyanate-acid phenol method (37). After electrophoresis through denaturing 1.2\% formaldehyde-agarose gels, RNA samples were transferred to nylon membranes (GeneScreen, New England Nuclear, Boston, MA), and rRNA distribution was visualized by methylene blue staining (38). Northern blots were hybridized sequentially with specific cDNA probes labeled either with $\left[\alpha^{32} \mathrm{P}\right] \mathrm{dCTP}$ by using the random priming method or with $\left[\alpha^{32} \mathrm{P}\right] \mathrm{CTP}$ labeled cRNA probes (39). For 28S rRNA analysis, an oligonucleotide complementary to nucleotides 4205-4225 (provided by Dr. E. W. Müllner) was end-labeled with $\left[\gamma-{ }^{32} \mathrm{P}\right] \mathrm{ATP}$ using poly-nucleotide kinase. After samples were washed, filters were exposed and quantified by phosphorimaging (Molecular Dynamics, Sunnyvale, CA). The background from each sample was subtracted by using the local median algorithm of the program ImageQuant (v.1.2, Molecular Dynamics).

\section{DNA fragmentation assays}

Analysis of DNA fragmentation was carried out as described previously (40), followed by incubation with $10 \mu \mathrm{g}$ of RNase A $\left(30 \mathrm{~min}, 37^{\circ} \mathrm{C}\right)$, subsequent electrophoresis in $2 \%$ agarose gels, visualization by ethidium bromide staining, and photography after UV light exposure. 


\section{RESULTS}

\section{CD95-induced apoptosis triggers degradation of cytoplasmic mRNAs}

Direct CD95 cross-linking with its specific ligand (Fas-L) or with agonistic mAb induces apoptosis in activated T cells and T-cell lymphomas (41). In Jurkat cells treated with $50 \mathrm{ng} / \mathrm{ml}$ anti-CD95 mAb, onset of apoptosis can be ascertained by 1) appearance of phosphatidylserine in the outer cell membrane, as measured by annexin $\mathrm{V}$ binding; 2) processing of the caspase substrate PARP; and 3) degradation of nuclear DNA, quantified by an increase in the fraction of cells in the sub- $\mathrm{G}_{0} / \mathrm{G}_{1}$ cell cycle phase. As early as $1 \mathrm{~h}$ after apoptotic insult, there was a significant increase in the amount of processed PARP and detectable annexin $\mathrm{V}$ binding, both of which increased over time. At $5 \mathrm{~h}$ after CD95 triggering, $62 \%$ of cells were positive for annexin $\mathrm{V}$ and the vast majority of PARP had been processed (Fig. 1A). These changes were followed by an increase in the fraction of cells in the sub- $\mathrm{G}_{0} / \mathrm{G}_{1}$ cell cycle phase (Fig. $\left.1 A\right)$. Thus, this model functions as a suitable tool for analysis of the fate of cellular mRNA during apoptosis.

The analysis of the mRNAs coding for the T-cell receptor $\beta$ chain (TCR $\beta$ ), major histocompatibility complex (MHC) class I $\alpha$-chain (HLA-I), and $\beta$-actin revealed a substantial decrease in expression levels of all these mRNAs after induction of apoptosis (Fig. 1B ) because of mRNA degradation (see below). mRNA degradation kinetics paralleled the appearance of annexin V-positive cells and preceded nuclear DNA fragmentation (Fig. 1C). In addition, the methylene blue staining pattern of RNA samples indicated degradation of 28S rRNA (Fig. $1 B$, open arrowheads). Specificity of apoptotis-induced mRNA degradation was demonstrated by processing Jurkat cells alone (-A20) or mixed, before lysis and RNA preparation, with A20 mouse control cells $(+\mathrm{A} 20)$, followed by Northern hybridization with human- and mousespecific probes. Similar degradation kinetics were observed for human mRNAs when samples of Jurkat cells were processed either alone $(-\mathrm{A} 20)$ or mixed with nonapoptotic control cells $(+\mathrm{A} 20)$, whereas mouse-specific IA $\alpha$ mRNA levels remained unchanged in samples containing control cells $(+\mathrm{A} 20)$ and were undetectable in samples devoid of control cells $(-\mathrm{A} 20)$. Taken together, these data indicate that CD95 triggering induces specific mRNA degradation, as part of the early apoptotic response, in Jurkat cells.

The Jurkat cell model also allowed analysis of mRNA degradation during AICD, one of the major mechanisms controlling immune system homeostasis (1). The fate of genes expressed in a constitutive (TCR $\beta$, HLA-I, and $\beta$-actin) or inducible (early activation marker CD69) fashion, as well as $28 \mathrm{~S}$ rRNA, was analyzed in JHM12 cells after carbachol treatment, which induces AICD in these cells (35). In agreement with the findings for CD95-induced apoptosis, all mRNAs analyzed after AICD were rapidly degraded, which correlated with the appearance of annexin V binding (Fig. 2). The similar degradation kinetics of Jurkat mRNAs in the presence $(+A 20)$ or absence (-A20) of control cells, whereas the A20-specific mRNA (IA $\alpha$ ) remained intact (Fig. 2), again indicated specificity of the apoptosis-induced mRNA degradation. The apparent difference in $\beta$-actin degradation kinetics between samples containing Jurkat mRNAs alone or mixed with A20 can be explained by the cross-reactivity of this probe between mouse and human samples (Fig. 2). The 28S rRNA probe also cross-reacts with mouse and human samples, but degradation of this rRNA could be quantified by appearance of specific degradation products (a 20-fold 
increase in the $28 \mathrm{~S}$ rRNA degradation product was concomitant with a 5- to 33-fold degradation of the mRNAs $8 \mathrm{~h}$ after apoptosis triggering) (Fig. $2 A$ ), which showed similar kinetics in the presence or absence of control A20 cells (Fig. 2B, inset).

These data show that after apoptosis induction in Jurkat cells, by either direct CD95 crosslinking or AICD, cytoplasmic mRNA degradation is an early event, concomitant with the appearance of annexin V-positive cells (Figs. 1 and 2). This degradation affects all mRNAs analyzed, independently of the transcriptional status of the gene, as well as $28 \mathrm{~S}$ rRNA.

To demonstrate that the apoptosis-induced decline in mRNA hybridization signals was indeed due to an active degradation rather than to an apoptosis-induced transcriptional arrest, mRNAs half-lives in nonapoptotic cells were analyzed and shown to be different from the apoptosisinduced degradation kinetics. Cells were preactivated with carbachol $(1 \mathrm{~h})$ before transcription was blocked with actinomycin D, to allow mRNA half-life analysis of activation-inducible (CD69) transcripts and of constitutive mRNAs. This short activation is not sufficient to trigger apoptosis because, during the course of the experiment, there was no significant increase in the fraction of annexin V-positive cells and PARP processing was detected only at longer times ( $>3$ $\mathrm{h}$, even in the absence of transcription inhibitors, not shown). In JHM12 cells, CD69 mRNA had a short half-life (about $20 \mathrm{~min}$ ), as previously reported (42), whereas the other mRNAs did not decay significantly during the course of the experiment (Fig. 3). Actinomycin D treatment, although restricted to $4 \mathrm{~h}$ because of toxicity at longer treatment times, allowed us to estimate that HLA-I, $\beta$-actin, and TCR $\beta$ mRNA half-lives were longer than $10 \mathrm{~h}$, in accordance with published data $(43,44)$. Thus, mRNAs with different half-lives showed similar apoptosisinduced degradation kinetics, indicating that apoptosis-induced mRNA degradation is an active process.

\section{Apoptosis-induced mRNA degradation was a general event independent of cell type and apoptosis triggering pathway}

To exclude the possibility that apoptosis-induced mRNA degradation was restricted to the JHM12 Jurkat T-cell clone, apoptosis was induced in mouse A20 cells (used as control in the above experiments) by direct CD95 cross-linking with mAb. A20 mRNAs (IA $\alpha$, BAX) were degraded during CD95-induced apoptosis, whereas HLA-I mRNA from mixed control Jurkat cells remained intact (Fig. 4), which again demonstrated the specificity of the apoptosis-induced mRNA degradation. The kinetics of apoptosis-induced mRNA degradation also correlated with increased annexin $\mathrm{V}$ binding. These data demonstrated that apoptosis-induced mRNA degradation was not restricted by cell line and strengthened the idea that it is an early general mechanism affecting different mRNAs, including those encoding proteins implicated in cell death, such as the proapoptotic protein $\operatorname{BAX}(45,46)$.

In addition to AICD, growth factor deprivation is the other major mechanism that induces T-cell apoptosis and allows maintenance of T-cell homeostasis after clonal expansion. The IL-2dependent murine cytotoxic $\mathrm{T}$ lymphocyte cell line CTLL-2 was used as a model for growth factor deprivation-induced apoptosis. In these cells, IL-2 withdrawal induced an increase in the sub- $\mathrm{G}_{0} / \mathrm{G}_{1}$ cell fraction, which indicated DNA degradation (Fig. 5A $)$. It is noteworthy that in comparison to CD95 cross-linking and AICD, the appearance of annexin V-positive cells was 
delayed, rather than preceding DNA fragmentation, and had kinetics similar to the kinetics of DNA fragmentation ( $\underline{\text { Fig. } 5 B}$ ). 28S rRNA degradation and appearance of the characteristic intermediates were detectable within $12 \mathrm{~h}$ after growth factor withdrawal (Fig. 5A). $\beta$-Actin mRNA, as an example of cytoplasmic transcript, was also degraded as an early event detectable after $12 \mathrm{~h}$, in fact preceding both the appearance of annexin $\mathrm{V}$ binding and DNA fragmentation (Fig. 5B).

\section{Distinct pathways lead to mRNA degradation and other apoptotic hallmarks after CD95 cross-linking}

Because CD95-induced apoptosis is inhibited by the general caspase inhibitor Z-VAD-fmk, its effect on apoptosis-induced mRNA degradation was analyzed. As expected, pretreatment with $100 \mu \mathrm{M}$ Z-VAD-fmk inhibited the increases in annexin V binding, cells in the sub- $\mathrm{G}_{0} / \mathrm{G}_{1}$ phase of the cell cycle, and PARP processing, which were induced by $5 \mathrm{~h}$ anti-CD95 $\mathrm{mAb}$, as well as

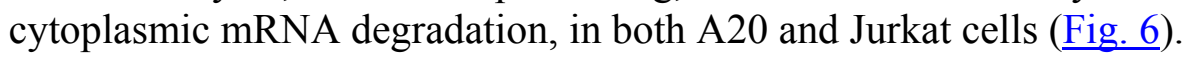

When apoptosis was induced in A20 cells for $6 \mathrm{~h}$ with anti-CD95, and the caspase inhibitor ZVAD-fmk was added at different times, conditions could be defined in which all described apoptotic events, except for mRNA degradation, were abrogated. Indeed, whereas Z-VAD-fmk addition either $1 \mathrm{~h}$ before or at the same time as anti-CD95 led to complete inhibition of all apoptotic markers including mRNA degradation, its addition $0.5 \mathrm{~h}$ after anti-CD95 mAb revealed degradation of more than $50 \%$ of the mRNA, with no detectable PARP processing and only background levels of DNA degradation or annexin V binding (Fig. 7). When Z-VAD-fmk was added at later times after CD95 triggering, a similar fraction of mRNA was degraded, concomitant with a progressive increase in PARP processing, annexin V-positive cells, and cells in the sub- $\mathrm{G}_{0} / \mathrm{G}_{1}$ phase of the cell cycle ( $\left.\underline{\text { Fig. 7 }}\right)$. Similar results were obtained with JHM12 cells (not shown). Thus, these data allowed us to conclude that apoptosis-induced mRNA degradation can occur in the absence of other apoptotic markers. Z-VAD-fmk inhibition kinetics also showed striking differences between mRNA degradation and annexin $\mathrm{V}$ binding, DNA degradation, and PARP degradation, the last three being progressively abrogated. This result indicates that antiCD95 mAb triggers different downstream signaling pathways, one responsible for annexin $\mathrm{V}$ binding, DNA fragmentation, and PARP processing, and the other implicated in mRNA degradation.

In addition, mRNA degradation was analyzed in JHM12-p35 cells, in which anti-CD95 mAbinduced apoptosis was completely blocked by constitutive expression of the baculoviral caspase inhibitor p35. Indeed, p35 expression abrogated DNA fragmentation and inhibited appearance of annexin V-positive cells. Most interesting, although the cells kept proliferating at the same rate, a substantial fraction of mRNA was still degraded (Fig. 8). These data further substantiate the notion of a distinct downstream signaling pathway responsible for mRNA degradation during apoptosis.

Taken together, these data show that apoptosis induces, as an early event, degradation of mRNAs with different intrinsic half-lives by an active process, as demonstrated by transcriptionblocking experiments. The pathways can be dissected from the one leading to the other apoptotic 
hallmarks. These data also demonstrate that although apoptosis-induced mRNA degradation is not restricted by cell line or stimuli, it is not sufficient to induce cell death.

\section{Apoptosis-induced mRNA degradation occurs in vivo as an early apoptotic event}

To determine whether apoptosis-induced mRNA degradation was a general apoptosis marker rather than restricted to cell lines, we extended the analysis to an in vivo apoptosis model. In the thymus, TCR triggering leads to immature thymocyte elimination (negative selection). This process can be mimicked in F5-TCR mice by the injection of the antigen specifically recognized by the TCR, which leads to massive apoptosis of immature thymocytes $\left(\mathrm{CD} 4^{+} \mathrm{CD} 8^{+}\right)$.

Interestingly, PARP processing and DNA fragmentation could be detected in treated mouse thymocytes as early as 90 min after peptide injection, when no reduction in cell numbers had yet taken place, but not in thymocytes from control animals (PBS injected) (Fig. 9A, $\underline{B}$ ).

Thymocyte RNA was prepared either alone (-JHM12) or mixed with human control cells (+JHM12). Specific degradation of the two CD8 $\alpha$ mRNA species was demonstrated, without significant degradation of control human mRNA $(\mathrm{TCR} \beta)$ in the mixture (Fig. $9 C, \underline{D})$. In this in vivo model, mRNA degradation also affected a fraction of the transcripts higher than the corresponding fraction of cells with fragmented DNA (cells in the sub- $\mathrm{G}_{0} / \mathrm{G}_{1}$ phase of the cell cycle) (Fig. 9D).

\section{DISCUSSION}

The data presented here demonstrate that mRNA degradation is a general early apoptosisinduced event and that it can be dissected from other processes that occur during programmed cell death. The hallmarks of apoptosis are 1) chromosomal DNA fragmentation into mono- and polynucleosomes, detectable as a DNA ladder $(8)$; 2) caspase activation $(47,48)$, which leads to cleavage of specific protein substrates $(10,11,16,48,49)$, and 3$)$ phosphatidylserine exposure at the cell surface, detectable as annexin V binding (50). Recent data showed that apoptosis induces a broad spectrum of changes in cellular proteins (12). In addition, apoptosis-induced degradation of $28 \mathrm{~S}$ rRNA $(18,51,52)$, mitochondrial $16 \mathrm{~S}$ rRNA (53), and the Ro ribonucleoproteinassociated Y RNAs (19) has been reported, although so far nothing was known about the fate of cytoplasmic mRNAs.

The data reported here demonstrate degradation of cytoplasmic mRNAs during apoptosis. Specificity was shown by mixing experiments in which mRNAs derived from apoptotic cells were degraded, whereas control cell mRNAs remained intact. Apoptosis-induced mRNA degradation is not restricted to genes with a specific function, because besides $28 \mathrm{~S}$ rRNA, the mRNAs analyzed encode proteins implicated in cell type-specific functions, proteins such as HLA-I, IA $\alpha$, TCR $\beta$, and CD69; structural proteins such as $\beta$-actin; and proteins involved in the control of cell survival, such as BAX.

Apoptosis-induced specific RNA degradation is neither cell line nor species restricted, because it was observed in nontransformed mouse T-cell lines (CTLL-2) (Fig. 5), mouse B-cell lymphomas

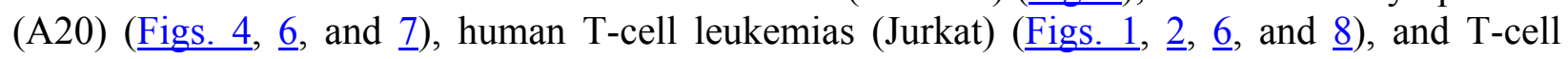


lymphomas (Molt-4) (not shown), as well as in mouse thymocytes in vivo (Fig. 9).

Furthermore, mRNA degradation, rather than being restricted to an apoptosis signaling pathway, was observed after triggering through Fas-mediated signaling pathways (CD95 cross-linking or AICD) (Figs. 1, 2, and 4) $(41,54,55)$, as well as by stimuli such as growth factor deprivation (Fig. 5) and okadaic acid treatment (data not shown), both independent of Fas $(29,56-58)$.

Taken together, these data indicate that apoptosis-induced mRNA degradation is not restricted by stimulus, cell line, or species and that it affects all mRNAs analyzed, which suggests that mRNA degradation is, at least in lymphocytes, a general feature of the cell death program. Indeed, in this report we demonstrate that mRNA degradation occurs upon apoptosis triggering by stimuli not requiring de novo transcription or translation, such as direct Fas triggering (Figs. $\underline{1}, \underline{4}, \underline{6}, \underline{7}$, and $\underline{8}$ ), and also upon AICD and growth factor deprivation (Figs. 2 and $\underline{5}$ ), both of which do require transcription and translation.

Kinetics studies showed that after Fas triggering or AICD, mRNA degradation precedes DNA degradation and correlates with the appearance of the early apoptotic marker annexin V (Figs. 1, $\underline{2}$, and 4). When apoptosis is induced by growth factor deprivation, however, the appearance of annexin V-positive cells and DNA fragmentation, which are preceded by mRNA degradation, have similar kinetics (Fig. 5). This result indicates that apoptosis-induced specific mRNA degradation is an early event and not simply the consequence of the metabolic collapse of the cell.

mRNA degradation is an active process rather than the consequence of an apoptosis-induced transcriptional blockade. Indeed, the intrinsic half-life of CD69 mRNA was very short (about 20 min, Fig. 3), and apoptosis induced an apparent stabilization, as demonstrated by the slower decay of the mRNA (about $1.5 \mathrm{~h}$, Fig. 2). Conversely, for other mRNAs (HLA-I, $\beta$-actin, and TCR $\beta$ ) with intrinsic long half-lives (>10 h, Fig. 3), apoptosis-induced degradation led to an increased turnover (about 2-3 h, Fig. 2). Apoptosis-induced degradation kinetics for all mRNAs analyzed were very similar ( $\beta$-actin, TCR $\beta$, HLA-I, IA $\alpha$, CD69, and BAX) (Figs. 1, 2 , and $\underline{4}$ ) and obviously independent of the intrinsic half-lives of the mRNAs in the cell.

Unlike $\beta$-actin, TCR $\beta$, or HLA-I transcripts, CD69 mRNA contains AU-rich elements (ARE) in its 3'-untranslated region (42), which destabilize otherwise stable mRNAs (59). Tight control of ARE-containing transcript stability occurs through interaction of these cis-regulatory elements with specific binding proteins involved in mRNA turnover (60). Apoptosis-induced CD69 mRNA decay has different, slower kinetics than its estimated half-life, which indicates that a mechanism different from ARE-mediated decay is implicated in apoptosis-induced degradation. Non-ARE-containing mRNAs are also degraded during apoptosis, although with faster kinetics than their corresponding half-lives, indicating that a specific mechanism is responsible for mRNA degradation triggered by apoptosis. This further substantiates the idea that mRNA degradation is a generalized feature of the apoptotic program.

In addition, the general caspase inhibitor Z-VAD-fmk (61) inhibited expression of all apoptotic markers including mRNA degradation (Fig. 6), whereas the more restricted caspase inhibitor 
p35, which completely blocks CD95-induced apoptosis, was unable to fully abrogate mRNA degradation (Fig. 8). The molecular mechanisms implicated in apoptosis-induced mRNA degradation are unknown. Nonetheless, it could be speculated that mRNA degradation depends on an upstream apical caspase (inhibited by Z-VAD-fmk but not p35) unable to cleave PARP. Conversely, it might be envisaged that in addition to caspases, Z-VAD-fmk inhibits other molecules (not inhibited by p35), including those responsible for RNase activation.

Kinetic analysis with caspase inhibitors not only allowed delineation of conditions in which mRNA degradation occurs in the absence of annexin V binding or DNA or PARP degradation but also demonstrated that the mechanisms involved in mRNA degradation were fully active as early as $0.5 \mathrm{~h}$ after Fas cross-linking, whereas inhibition of other apoptotic hallmarks was progressively abrogated (Fig. 7). These findings strongly suggest that the signaling pathways induced by anti-Fas $\mathrm{mAb}$ can be kinetically dissociated into one route leading to mRNA degradation and another one leading to PARP processing, annexin V binding, and DNA fragmentation. The baculoviral p35 experiments (Fig. 8) corroborated the notion that a distinct signaling pathway is responsible for mRNA degradation during apoptosis. Furthermore, extensive mRNA degradation, although apparently a general early apoptotic event, is not sufficient to induce cell death per se.

During maturation, thymocytes are subject to positive and negative selection processes, in which the large majority of cells die by apoptosis; only about 5\% of cells successfully complete maturation. The negative selection process has been mimicked in vivo in TCR transgenic mice by antigen injection, which leads to the elimination of the vast majority of $\mathrm{CD} 4^{+} \mathrm{CD} 8^{+}$ thymocytes $(36,40)$. Specific mRNA degradation in these cells was demonstrated as early as 90 min after antigen injection, preceding DNA degradation. This finding was thus a clear indication that apoptosis-induced mRNA degradation is a general early event that occurs not only in T-cell lines but also in vivo.

These observations raise a question about the nature of the RNases involved, which remains to be elucidated. By analogy to the CAD, which after cleavage of its specific inhibitor ICAD is activated and translocates to the nucleus (16), a similar model can be envisaged for a caspaseactivated RNase. CAD itself cannot be responsible for degradation of mRNA because 1) under conditions in which CAD was inhibited, there was still 28S rRNA degradation $(18,33), 2$ ) kinetic analysis with caspase inhibitors allowed differentiation of conditions in which mRNA degradation occurs in the absence of DNA degradation (Fig. 7), 3) similar results were obtained in Jurkat cells constitutively expressing the caspase inhibitor p35 (Fig. 8), and 4) the presence in Jurkat cells of DEVD (a caspase-3 inhibitor) prevented DNA fragmentation induced by antiCD95 mAb, whereas the mRNA was still degraded (not shown).

Detailed molecular analysis of apoptosis-induced 28S rRNA degradation products suggests that RNase L may be the RNase involved $(51,62)$. RNase L is found in nearly all mammalian cell types and tissues (63) and was initially described as an interferon-inducible enzyme (63). RNase $\mathrm{L}^{-/-}$mice show defective apoptosis in the thymus and spleen; in vitro thymocyte- and fibroblastinduced apoptosis is also defective (62). These findings, together with the similar decay kinetics of $28 \mathrm{~S}$ rRNA and mRNAs, allow us to hypothesize that RNase L may be one of the enzymes 
implicated in apoptosis-induced mRNA degradation. RNase L cleavage of 28S rRNA gives a defined pattern of readily detectable degradation intermediates $(51,62)$, similar to the pattern observed in the experiments presented here (Figs. 1, 2, and 4-7). For cytoplasmic mRNAs, however, degradation intermediates remained elusive so far (Figs. 1, 2, and 4-7), which may be due to the high degradation rate and the intrinsic difficulty of detecting degradation intermediates from transcripts of low or intermediate abundance or conversely may be interpreted as the involvement of different RNases in the degradation of cytoplasmic mRNAs. Further experiments are needed to identify RNase activities responsible for degradation of the bulk of cytoplasmic mRNAs.

Thus, apoptosis induces degradation of the cytoplasmic mRNAs but also degradation of $28 \mathrm{~S}$ rRNA and cleavage of translation initiation factors (eIF4GI, eIF4GII) $(64,65)$, which suggests that the cell, by different means, blocks protein synthesis, which may be a prerequisite for reaching the "point of no return" in the cell death program. Furthermore, degradation of cellular mRNA is a general early apoptotic event, which may be considered a hallmark of apoptosis. This finding has clear implications in the field of mRNA turnover, as well as for the physiology of apoptosis, because it demonstrates for the first time a generalized change in mRNA stablility induced by an external stimuli and, in addition, will have to be taken into account in experiments aimed at identifying genes involved in the cell death process.

\section{ACKNOWLEDGMENTS}

This work was supported in part by an EU-TMR Network grant (contract number: ERBFMRXCT980197), to J. A. G. S. M.S.R. is the recipient of a fellowship from the Comunidad de Madrid. The Department of Immunology and Oncology was founded and is supported by the Spanish Council for Scientific Research (CSIC) and by the Pharmacia Corporation. We are grateful to Drs. F. Erard, A. Brás, A. Weiss, and E. W. Müllner for providing cell lines and reagents; to Dr. D. Kioussis (MRC, London) for providing the F5TCR mice; to Ms. M. Obrero for bacterial growth and plasmid preparation; to Mr. L. Gómez for animal work; to Ms. M. C. Moreno-Ortíz and Dr. I. López-Vidriero for help with FACS analysis; to Drs. B. Pradet-Balade, M. Campanero, M. Hahne, I. Mérida (DIO, CNB-CSIC), and E. W. Müllner (Vienna Biocenter) for critically reviewing the manuscript; and to Ms. C. Mark for editorial assistance.

\section{REFERENCES}

1. Nagata, S. (1997) Apoptosis by death factor. Cell 88, 355-365.

2. Thompson, C. B. (1995) Apoptosis in the pathogenesis and treatment of disease. Science 267, 1456-1462.

3. Hara, H., Friedlander, R. M., Gagliardini, V., Ayata, C., Fink, K., Huang, Z., Shimizu-Sasamata, M., Yuan, J. and Moskowitz, M. A. (1997) Inhibition of interleukin $1 \beta$ converting enzyme family proteases reduces ischemic and excitotoxic neuronal damage. Proc Natl Acad Sci USA 94, 2007-2012. 
4. Cotman, C. W. and Anderson, A. J. (1995) A potential role for apoptosis in neurodegeneration and Alzheimer's disease. Mol Neurobiol 10, 19-45.

5. Evan, G. (1997) Cancer---a matter of life and cell death. Int J Cancer 71, 709-711.

6. Evan, G. and Littlewood, T. (1998) A matter of life and cell death. Science 281, 1317-1322.

7. Kerr, J. F., Wyllie, A. H. and Currie, A. R. (1972) Apoptosis: a basic biological phenomenon with wide-ranging implications in tissue kinetics. Br J Cancer 26, 239-257.

8. Wyllie, A. H. (1980) Glucocorticoid-induced thymocyte apoptosis is associated with endogenous endonuclease activation. Nature (London) 284, 555-556.

9. Ashkenazi, A. and Dixit, V. M. (1998) Death receptors: signaling and modulation. Science 281, 1305-1308.

10. Nicholson, D. W. and Thornberry, N. A. (1997) Caspases: killer proteases. Trends Biochem Sci 22, 299-306.

11. Widmann, C., Gibson, S. and Johnson, G. L. (1998) Caspase-dependent cleavage of signaling proteins during apoptosis. A turn-off mechanism for anti-apoptotic signals. J Biol Chem 273, $7141-7147$.

12. Gerner, C., Frohwein, U., Gotzmann, J., Bayer, E., Gelbmann, D., Bursch, W. and SchulteHermann, R. (2000) The Fas-induced apoptosis analyzed by high throughput proteome analysis. J Biol Chem 275, 39018-39026.

13. Kaufmann, S. H. (1989) Induction of endonucleolytic DNA cleavage in human acute myelogenous leukemia cells by etoposide, camptothecin, and other cytotoxic anticancer drugs: a cautionary note. Cancer Res 49, 5870-5878.

14. Song, Q., Lees-Miller, S. P., Kumar, S., Zhang, Z., Chan, D. W., Smith, G. C., Jackson, S. P., Alnemri, E. S., Litwack, G., Khanna, K. K. and Lavin, M. F. (1996) DNA-dependent protein kinase catalytic subunit: a target for an ICE-like protease in apoptosis. EMBO J 15, 3238-3246.

15. Casciola-Rosen, L., Nicholson, D. W., Chong, T., Rowan, K. R., Thornberry, N. A., Miller, D. K. and Rosen, A. (1996) Apopain/CPP32 cleaves proteins that are essential for cellular repair: a fundamental principle of apoptotic death. J Exp Med 183, 1957-1964.

16. Enari, M., Sakahira, H., Yokoyama, H., Okawa, K., Iwamatsu, A. and Nagata, S. (1998) A caspase-activated DNase that degrades DNA during apoptosis, and its inhibitor ICAD. Nature (London) 391, 43-50.

17. Cidlowski, J. A. (1982) Glucocorticoids stimulate ribonucleic acid degradation in isolated rat thymic lymphocytes in vitro. Endocrinology 111, 184-190. 
18. Nadano, D. and Sato, T. A. (2000) Caspase-3-dependent and -independent degradation of $28 \mathrm{~S}$ ribosomal RNA may be involved in the inhibition of protein synthesis during apoptosis initiated by death receptor engagement. $J$ Biol Chem 275, 13967-13973

19. Rutjes, S. A., van der Heijden, A., Utz, P. J., van Venrooij, W. J. and Pruijn, G. J. (1999) Rapid nucleolytic degradation of the small cytoplasmic Y RNAs during apoptosis. J Biol Chem 274, 24799-24807.

20. Shortman, K., Egerton, M., Spangrude, G. J. and Scollay, R. (1990) The generation and fate of thymocytes. Semin Immunol 2, 3-12.

21. Surh, C. D. and Sprent, J. (1994) T-cell apoptosis detected in situ during positive and negative selection in the thymus. Nature (London) 372, 100-103.

22. Sytwu, H. K., Liblau, R. S. and McDevitt, H. O. (1996) The roles of Fas/APO-1 (CD95) and TNF in antigen-induced programmed cell death in T cell receptor transgenic mice. Immunity $\mathbf{5}$, 17-30.

23. Arch, R. H. and Thompson, C. B. (1999) Lymphocyte survival---the struggle against death. Annu Rev Cell Dev Biol 15, 113-140

24. Russell, J. H. (1995) Activation-induced death of mature T cells in the regulation of immune responses. Curr Opin Immunol 7, 382-388.

25. Shi, Y. F., Sahai, B. M. and Green, D. R. (1989) Cyclosporin A inhibits activation-induced cell death in T-cell hybridomas and thymocytes. Nature (London) 339, 625-626.

26. Green, D. R. and Scott, D. W. (1994) Activation-induced apoptosis in lymphocytes. Curr Opin Immunol 6, 476-487.

27. Rieux-Laucat, F., Le Deist, F., Hivroz, C., Roberts, I. A., Debatin, K. M., Fischer, A. and de Villartay, J. P. (1995) Mutations in Fas associated with human lymphoproliferative syndrome and autoimmunity. Science 268, 1347-1349.

28. Wang, J., Zheng, L., Lobito, A., Chan, F. K., Dale, J., Sneller, M., Yao, X., Puck, J. M., Straus, S. E. and Lenardo, M. J. (1999) Inherited human caspase 10 mutations underlie defective lymphocyte and dendritic cell apoptosis in autoimmune lymphoproliferative syndrome type II. Cell 98, 47-58.

29. Hieronymus, T., Blank, N., Gruenke, M., Winkler, S., Haas, J. P., Kalden, J. R. and Lorenz, H. M. (2000) CD 95-independent mechanisms of IL-2 deprivation-induced apoptosis in activated human lymphocytes. Cell Death Differ 7, 538-547.

30. Lanier, L. L., Warner, N. L., Ledbetter, J. A. and Herzenberg, L. A. (1981) Quantitative immunofluorescent analysis of surface phenotypes of murine B cell lymphomas and plasmacytomas with monoclonal antibodies. J Immunol 127, 1691-1697 
31. Gillis, S., Ferm, M. M., Ou, W. and Smith, K. A. (1978) T cell growth factor: parameters of production and a quantitative microassay for activity. J Immunol 120, 2027-2032

32. Goldsmith, M. A., Desai, D. M., Schultz, T. and Weiss, A. (1989) Function of a heterologous muscarinic receptor in T cell antigen receptor signal transduction mutants. $J$ Biol Chem 264, $17190-17197$

33. Samali, A., Gilje, B., Doskeland, S. O., Cotter, T. G. and Houge, G. (1997) The ability to cleave $28 \mathrm{~S}$ ribosomal RNA during apoptosis is a cell-type dependent trait unrelated to DNA fragmentation. Cell Death Differ 4, 289-293.

34. Karasuyama, H. and Melchers, F. (1988) Establishment of mouse cell lines which constitutively secrete large quantities of interleukin 2, 3, 4 or 5 using modified cDNA expression vectors. Eur $J$ Immunol 18, 98-104

35. Izquierdo, M., Ruiz-Ruiz, M. C. and Lopez-Rivas, A. (1996) Stimulation of phosphatidylinositol turnover is a key event for Fas-dependent, activation-induced apoptosis in human $\mathrm{T}$ lymphocytes. J Immunol 157, 21-28

36. Mamalaki, C., Norton, T., Tanaka, Y., Townsend, A. R., Chandler, P., Simpson, E. and Kioussis, D. (1992) Thymic depletion and peripheral activation of class I major histocompatibility complex-restricted T cells by soluble peptide in T-cell receptor transgenic mice. Proc Natl Acad Sci USA 89, 11342-11346.

37. Müllner, E. W. and Garcia-Sanz, J. A. (1997) Preparation of RNA. In Immunology Methods Manual (Lefkovits, I., ed.), Vol. 1, pp. 389-406, Academic Press, London.

38. Müllner, E. W. and Garcia-Sanz, J. A. (1997) Analysis of RNA Expression by Northern Blotting. In Immunology Methods Manual (Lefkovits, I., ed.), Vol. 1, pp. 407-424, Academic Press,

39. Goñalons, E., Barrachina, M., Garcia-Sanz, J. A. and Celada, A. (1998) Translational control of MHC class II I-A molecules by INF $\gamma$. J Immunol 161, 1837-1843.

40. Mamalaki, C., Tanaka, Y., Corbella, P., Chandler, P., Simpson, E. and Kioussis, D. (1993) T cell deletion follows chronic antigen specific T cell activation in vivo. Int Immunol 5, 1285-1292.

41. Trauth, B. C., Klas, C., Peters, A. M., Matzku, S., Moller, P., Falk, W., Debatin, K. M. and Krammer, P. H. (1989) Monoclonal antibody-mediated tumor regression by induction of apoptosis. Science 245, 301-305.

42. Santis, A. G., Lopez-Cabrera, M., Sanchez-Madrid, F. and Proudfoot, N. (1995) Expression of the early lymphocyte activation antigen CD69, a C-type lectin, is regulated by mRNA degradation associated with AU-rich sequence motifs. Eur J Immunol 25, 2142-2146. 
43. Lu, P., Garcia-Sanz, J. A., Lichtenheld, M. G. and Podack, E. R. (1992) Perforin expression in human peripheral blood mononuclear cells. Definition of an IL-2-independent pathway of perforin induction in $\mathrm{CD}^{+} \mathrm{T}$ cells. $J$ Immunol 148, 3354-3360.

44. Garcia-Sanz, J. A. and Podack, E. R. (1993) Regulation of perforin gene expression in a T cell hybrid with inducible cytolytic activity. Eur J Immunol 23, 1877-1883.

45. Korsmeyer, S. J. (1995) Regulators of cell death. Trends Genet 11, 101-105.

46. Adams, J. M. and Cory, S. (1998) The Bcl-2 protein family: arbiters of cell survival. Science 281, 1322-1326.

47. Takahashi, A. and Earnshaw, W. C. (1996) ICE-related proteases in apoptosis. Curr Opin Genet Dev 6, 50-55.

48. Cohen, G. M. (1997) Caspases: the executioners of apoptosis. Biochem J 326, 1-16.

49. Affar, E. B., Germain, M., Winstall, E., Vodenicharov, M., Shah, R. G., Salvesen, G. S. and Poirier, G. G. (2001) Caspase-3-mediated processing of poly(ADP-ribose) glycohydrolase during apoptosis. $J$ Biol Chem 276, 2935-2942.

50. Martin, S. J., Reutlingsperger, C. P., McGahon, A. J., Rader, J. A., van Schie, R. C., LaFace, D. M. and Green, D. R. (1995) Early redistribution of plasma membrane phosphatidylserine is a general feature of apoptosis regardless of the initiating stimulus: inhibition by overexpression of Bcl-2 and Abl. $J$ Exp Med 182, 1545-1556.

51. Houge, G., Robaye, B., Eikhom, T. S., Golstein, J., Mellgren, G., Gjertsen, B. T., Lanotte, M. and Doskeland, S. O. (1995) Fine mapping of 28S rRNA sites specifically cleaved in cells undergoing apoptosis. Mol Cell Biol 15, 2051-2062.

52. King, K. L., Jewell, C. M., Bortner, C. D. and Cidlowski, J. A. (2000) 28S ribosome degradation in lymphoid cell apoptosis: evidence for caspase and Bcl-2-dependent and -independent pathways. Cell Death Differ 7, 994-1001.

53. Crawford, D. R., Lauzon, R. J., Wang, Y., Mazurkiewicz, J. E., Schools, G. P. and Davies, K. J. (1997) 16S mitochondrial ribosomal RNA degradation is associated with apoptosis. Free Radic Biol Med 22, 1295-1300

54. Yonehara, S., Ishii, A. and Yonehara, M. (1989) A cell-killing monoclonal antibody (anti-Fas) to a cell surface antigen co-downregulated with the receptor of tumor necrosis factor. $J$ Exp Med 169, 1747-1756.

55. Suda, T., Takahashi, T., Golstein, P. and Nagata, S. (1993) Molecular cloning and expression of the Fas ligand, a novel member of the tumor necrosis factor family. Cell 75, 1169-1178. 
56. Lenardo, M., Chan, K. M., Hornung, F., McFarland, H., Siegel, R., Wang, J. and Zheng, L. (1999) Mature T lymphocyte apoptosis---immune regulation in a dynamic and unpredictable antigenic environment. Annu Rev Immunol 17, 221-253

57. Smith, K. G., Strasser, A. and Vaux, D. L. (1996) CrmA expression in T lymphocytes of transgenic mice inhibits CD95 (Fas/APO-1)-transduced apoptosis, but does not cause lymphadenopathy or autoimmune disease. EMBO J15, 5167-5176.

58. Strasser, A., Harris, A. W., Huang, D. C., Krammer, P. H. and Cory, S. (1995) Bcl-2 and Fas/APO-1 regulate distinct pathways to lymphocyte apoptosis. EMBO J 14, 6136-6147.

59. Shaw, G. and Kamen, R. (1986) A conserved AU sequence from the 3' untranslated region of GM-CSF mRNA mediates selective mRNA degradation. Cell 46, 659-667.

60. Shyu, A. B. and Wilkinson, M. F. (2000) The double lives of shuttling mRNA binding proteins. Cell 102, 135-138.

61. Ekert, P. G., Silke, J. and Vaux, D. L. (1999) Caspase inhibitors. Cell Death Differ 6, 1081-1086.

62. Zhou, A., Paranjape, J., Brown, T. L., Nie, H., Naik, S., Dong, B., Chang, A., Trapp, B., Fairchild, R., Colmenares, C. and Silverman, R. H. (1997) Interferon action and apoptosis are defective in mice devoid of 2',5'-oligoadenylate-dependent RNase L. EMBO J 16, 6355-6363.

63. Silverman, R. H. (1997) 2-5A Dependent RNase L: A Regulated Endoribonuclease in the Interferon System. In Ribonucleases: Structure and Function (D'Alessio, G. and Riordan, J. F., eds.), pp. 515-551, Academic Press, New York

64. Clemens, M. J., Bushell, M. and Morley, S. J. (1998) Degradation of eukaryotic polypeptide chain initiation factor (eIF) $4 \mathrm{G}$ in response to induction of apoptosis in human lymphoma cell lines. Oncogene 17, 2921-2931.

65. Marissen, W. E., Gradi, A., Sonenberg, N. and Lloyd, R. E. (2000) Cleavage of eukaryotic translation initiation factor 4GII correlates with translation inhibition during apoptosis. Cell Death Differ 7, 1234-1243. 
Fig. 1

A

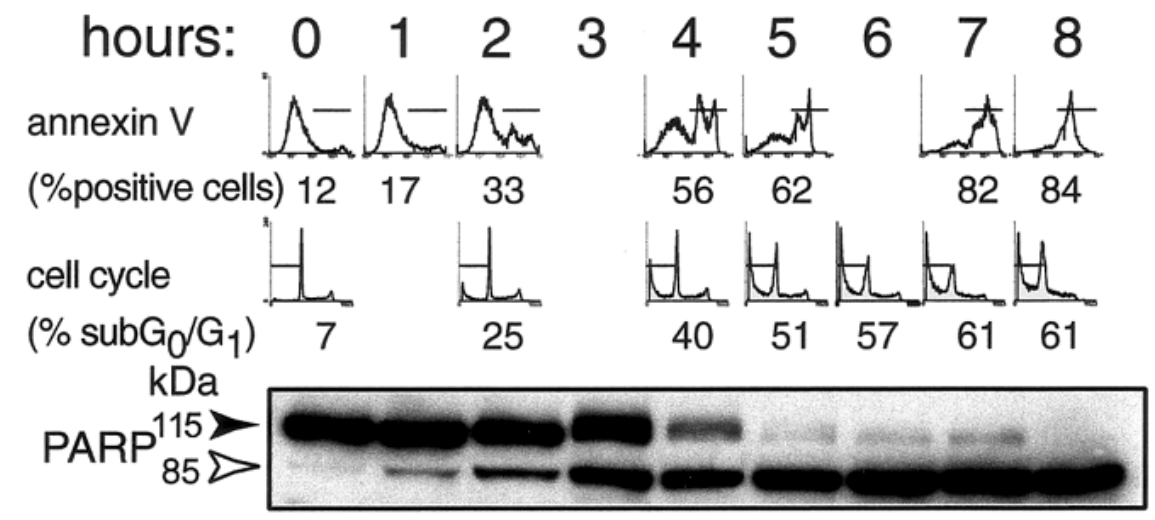

B
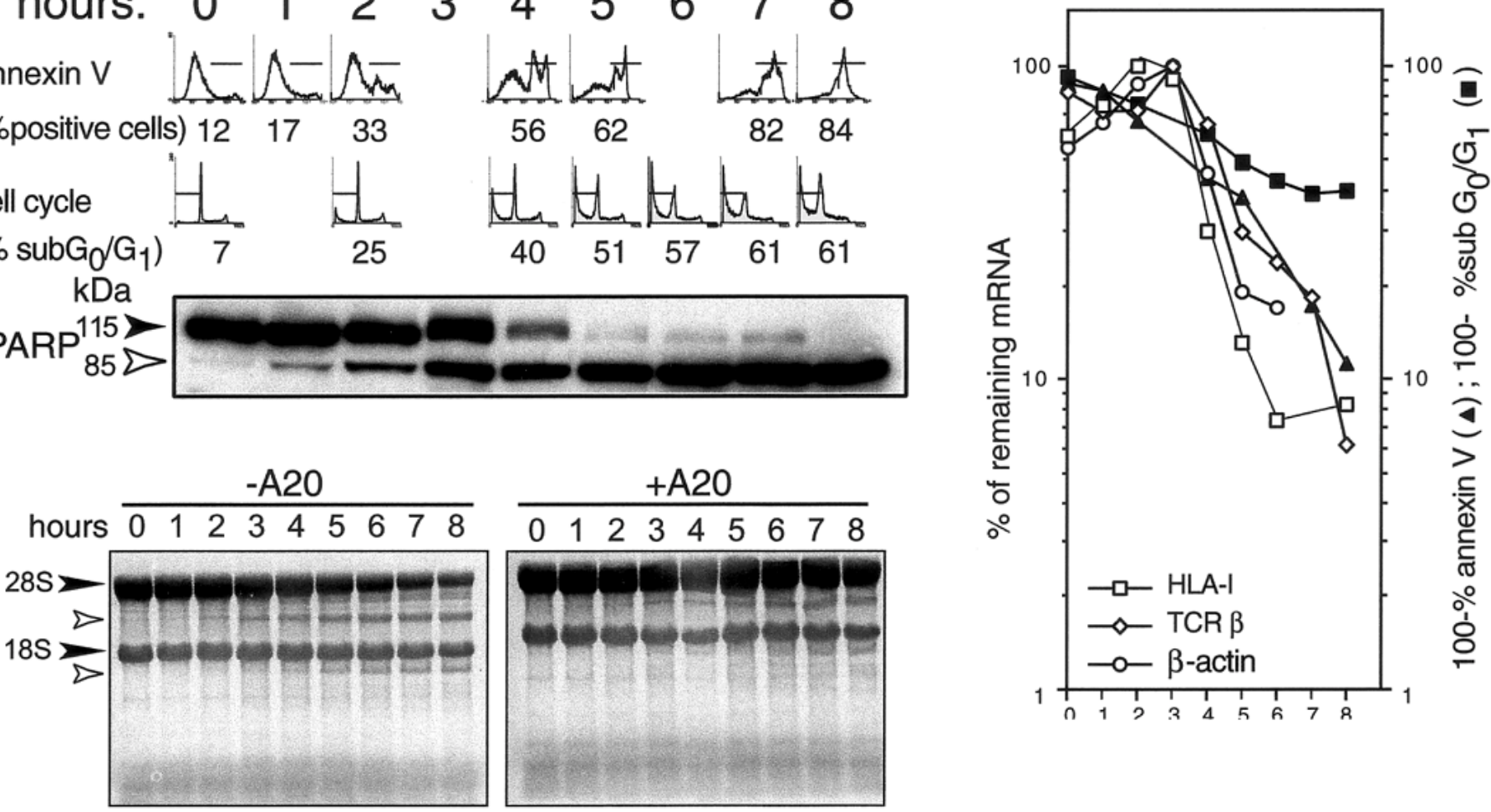

JHM12 TCR $\beta$
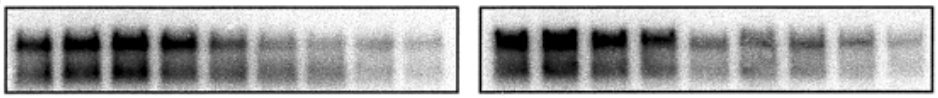

HLA-I
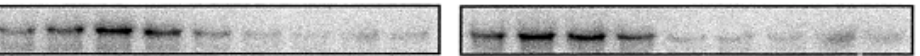

A20

$I A \alpha$

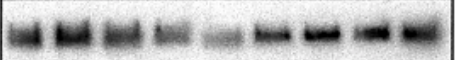

Figure 1. Direct triggering of death receptors induced specific mRNA degradation. Representative experiment showing the kinetics of annexin V binding, DNA degradation, PARP processing, and mRNA degradation after Fas triggering. $\boldsymbol{A}$ ) The kinetics of apoptosis induction after anti-Fas treatment was quantified as the fraction of cells positive for annexin $V$, cells in the sub- $\mathrm{G}_{0} / \mathrm{G}_{1}$ phase of the cell cycle, and kinetics of PARP processing (115 kDa, unprocessed form; $85 \mathrm{kDa}$, processed form) (empty boxes indicate that the analysis at that time point was not determined). B) Northern blots of RNA from human JHM12 cells alone (-A20, left panels) or in combination with mouse control cells ( + A20, right panels), showing methylene blue staining of filters (top) and hybridization with specific JHM1 2 mRNAs (T-cell receptor $\beta$ chain [TCR $\beta$ ], HLA class I [HLA-I]), as well as hybridization with a probe specific for the mouse A20 control cells (MHC class II mRNA $[\mathrm{Ia} \alpha]) . \boldsymbol{C}$ ) Quantification of data from $\boldsymbol{A}$ and $\boldsymbol{B}$, represented for comparison purposes as 100 minus the percentage of annexin V-positive cells, or 100 minus the percentage of cells in the sub- $\mathrm{G}_{0} / \mathrm{G}_{1}$ phase of the cell cycle, and percentage of remaining mRNA for Northern blots, after correction of the specific signal for each transcript with the values obtained for the control IA $\alpha$ mRNA. 
Fig. 2
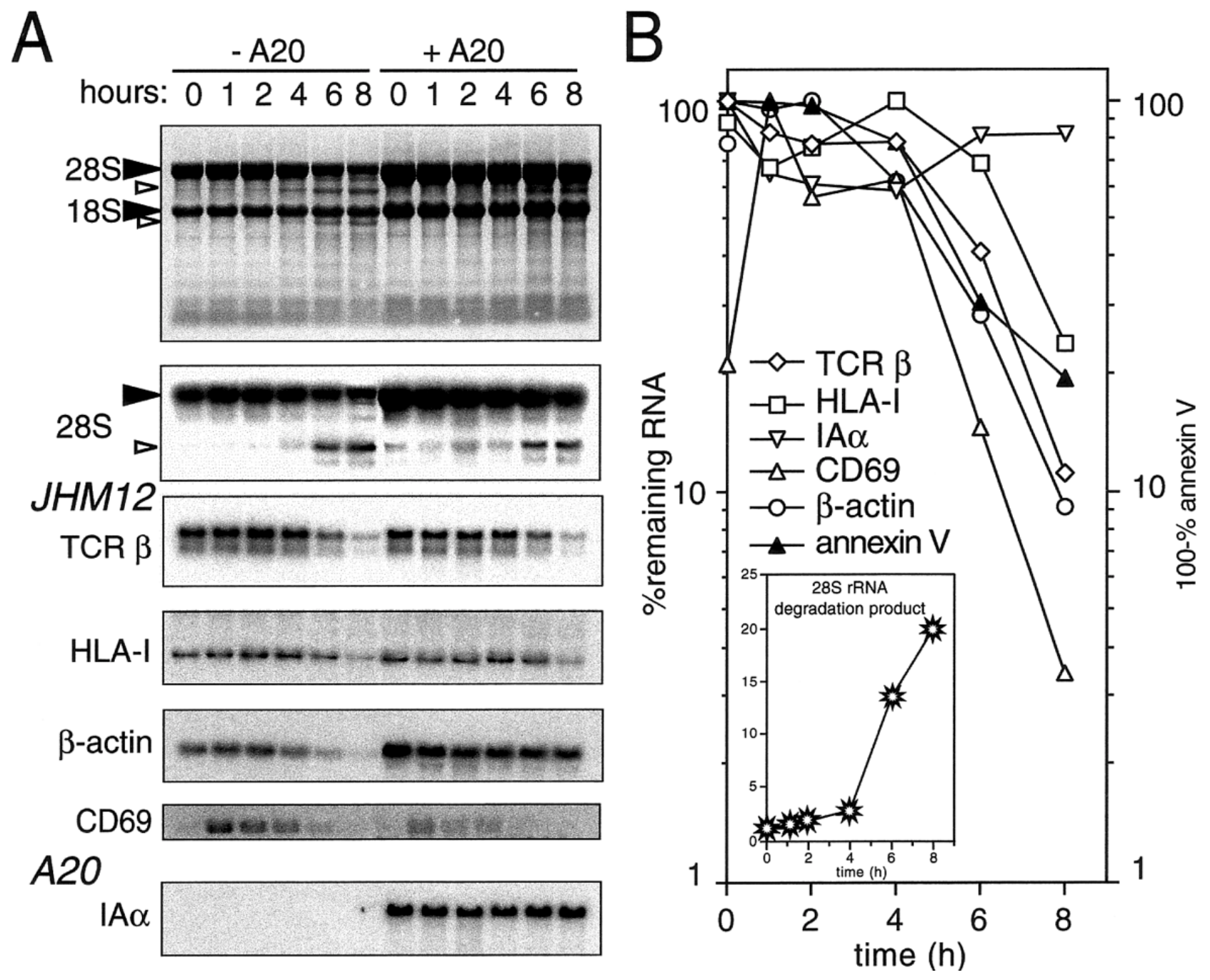

Figure 2. Apoptosis-induced cell death triggered mRNA degradation. After induction of AICD by carbachol in Jurkat JHM12 cells, the kinetics of cytoplasmic mRNA degradation were analyzed. A) Methylene blue staining of cytoplasmic RNA from Jurkat cells alone (-A20) or in combination with control cells (+A20) (staining, top panel). Relative expression levels are shown for $28 \mathrm{~S}$ rRNA, TCR $\beta$, HLA-I, $\beta$-actin, and CD69 in Jurkat cells, as well as for the A20 cell-specific IA $\alpha$ mRNA. Open arrowheads indicate 28S rRNA degradation products. B) Quantification of data in $A$, represented for all transcripts, including the control IA $\alpha$ mRNA, as a percentage of the remaining mRNA and the fraction of cells positive for annexin $\mathrm{V}$, which for comparative purposes is represented as 100 minus the percentage of annexin $\mathrm{V}$. The inset in $\boldsymbol{B}$ represents the appearance kinetics of the $28 \mathrm{~S}$ rRNA degradation product (open arrowhead in the $28 \mathrm{~S}$ rRNA panel in $\boldsymbol{A}$ ). 
Fig. 3

A

B
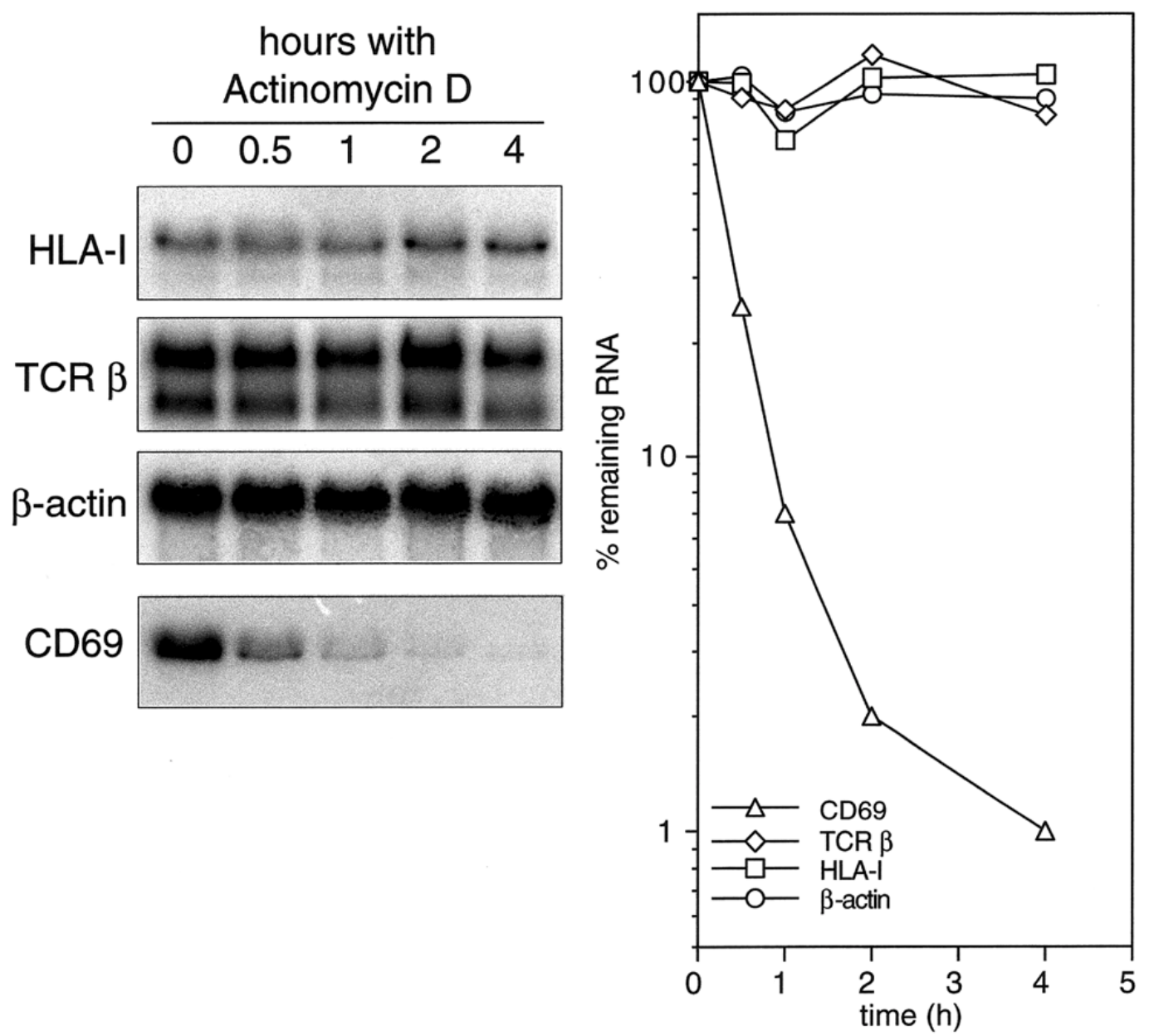

Figure 3. Analysis of mRNA turnover in Jurkat cells. After $1 \mathrm{~h}$ of carbachol activation of JHM12 cells and subsequent de novo transcription blockade with $5 \mu \mathrm{M}$ actinomycin D, turnover of CD69, TCRß, HLA-I, and B-actin mRNA was analyzed. Cells were harvested at different times $(0-4 \mathrm{~h})$ and cytoplasmic RNAs were prepared. $\boldsymbol{A})$ Northern hybridization with specific cDNA probes. $\boldsymbol{B})$ Quantification of hybridization data from $\boldsymbol{A}$. 
Fig. 4

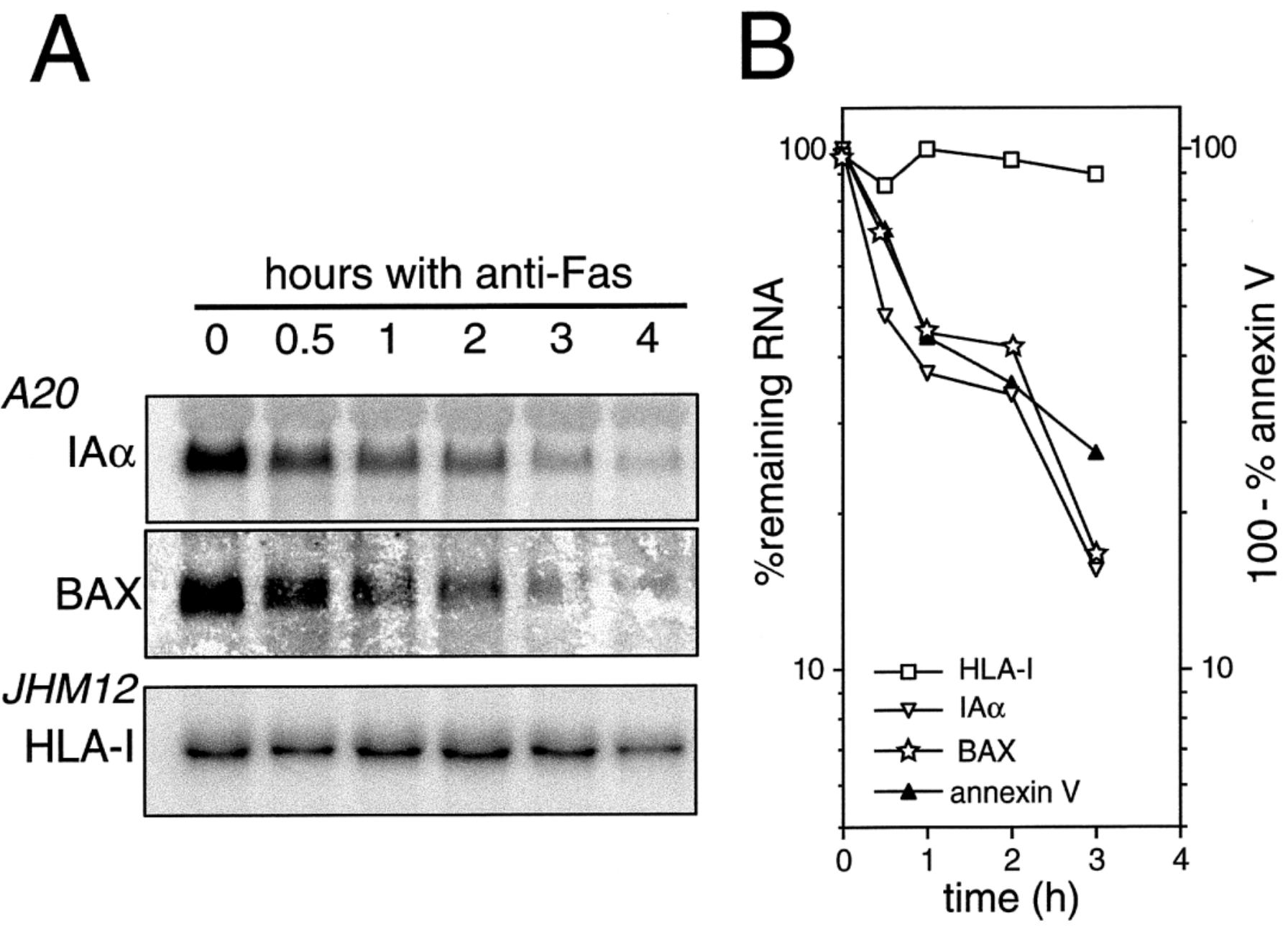

Figure 4. Apoptosis-induced mRNA degradation is not restricted by cell type. Analysis of CD95-induced mRNA degradation in mouse A20 cells. A) Northern blot showing degradation of A20 mRNAs (IA $\alpha$ and BAX), whereas mRNA from control JHM12 cells (HLA-I) remained intact. B) Quantification of data in $A$, represented for all transcripts, including the control HLA-I mRNA, as percentage of the remaining mRNA, together with the fraction of cells positive for annexin $\mathrm{V}$, which for comparative purposes is represented as 100 minus the percentage of annexin $\mathrm{V}$. 
Fig. 5

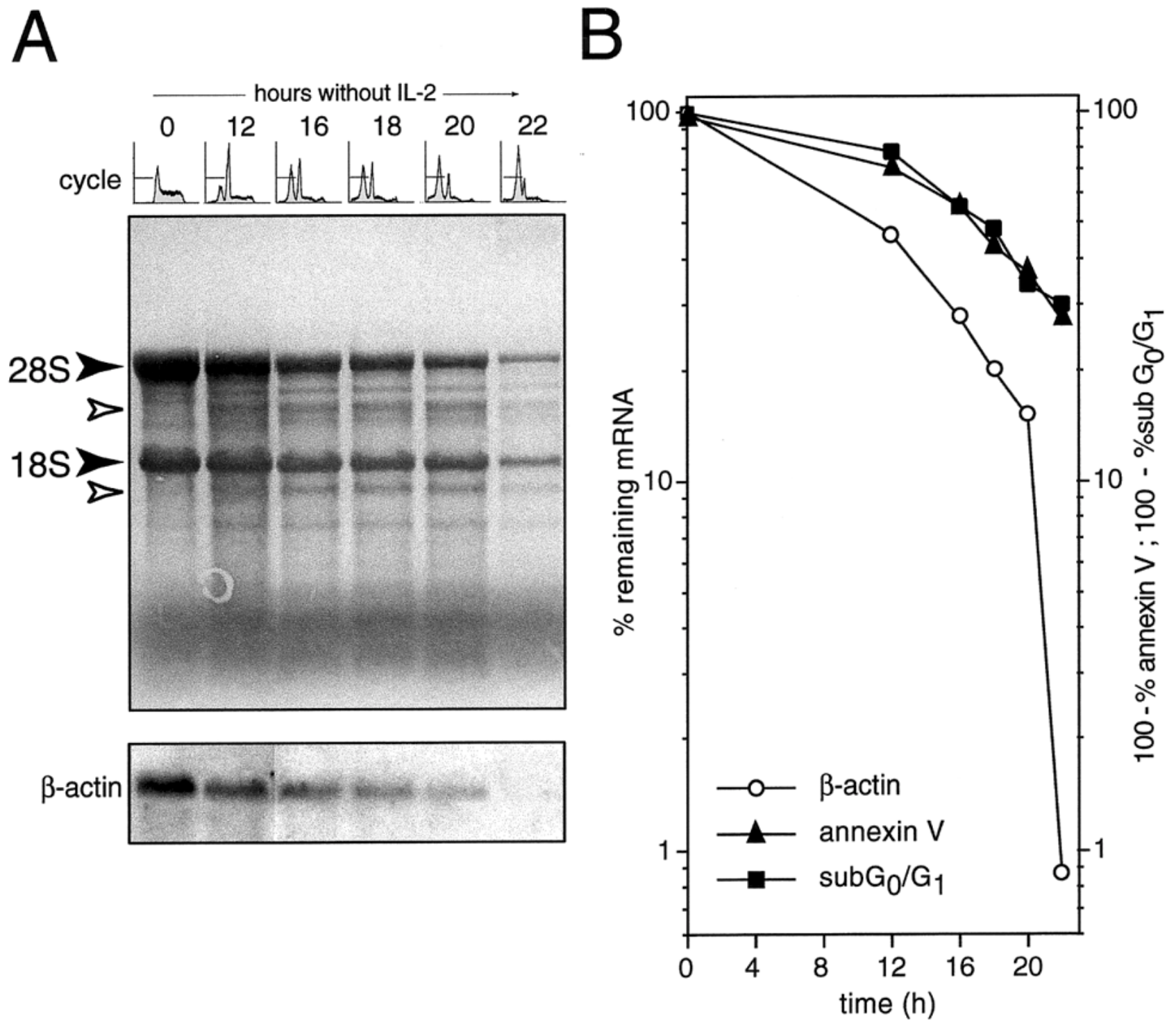

Figure 5. mRNA degradation after apoptosis induced by growth factor deprivation. Exponentially growing CTLL-2 cells were deprived of growth factor and cultured for different time periods (0-22 h) in the absence of IL-2. After cells were harvested, aliquots of cells were used to quantify the percentage of dead cells (annexin V staining and DNA degradation), as well as to prepare cytoplasmic RNA. A) Propidium iodine staining of permeabilized cells to determine the DNA profiles. Time-dependent degradation of $\beta$-actin mRNA and $28 \mathrm{~S}$ rRNA, concomitant with the appearance of $28 \mathrm{~S}$ degradation products. $\boldsymbol{B})$ Quantification of $\beta$-actin mRNA degradation kinetics, appearance of cells in the sub- $\mathrm{G}_{0} / \mathrm{G}_{1}$ phase of the cell cycle, and annexin V-positive cells. 
Fig. 6

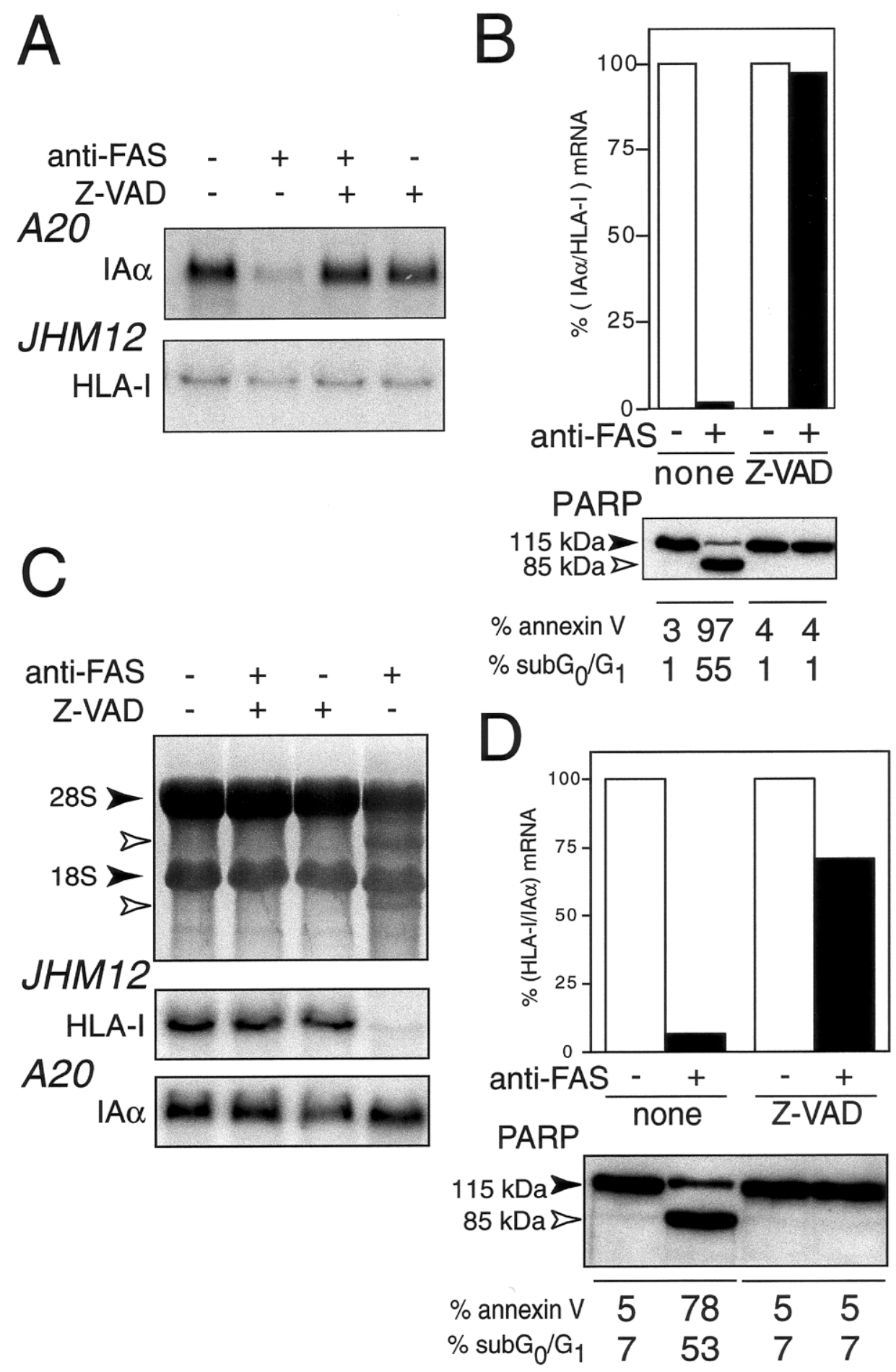

Figure 6. Apoptosis-induced mRNA degradation was inhibited by a general caspase inhibitor. Triggering of CD95 with specific mAbs induced apoptosis and specific mRNA degradation in both A20 $(\boldsymbol{A}, \boldsymbol{B})$ and JHM12 $(\boldsymbol{C}, \boldsymbol{D})$ cells. Treatment of cells with $100 \mu \mathrm{M}$ Z-VAD-fmk, before CD95 triggering for $5 \mathrm{~h}$, inhibited the appearance of the apoptotic markers DNA fragmentation, PARP processing, and annexin V-positive cells $(\boldsymbol{B}, \boldsymbol{D})$ and abrogated cytoplasmic mRNA degradation in both cell lines. In $\boldsymbol{A}$, A20 cells treated with Fas were mixed with JHM12 control cells, whereas in $\boldsymbol{C}$ the JHM12 cells were treated with Fas and mixed with A20 control cells. The quantified mRNA signals shown in $\boldsymbol{B}$ and $\boldsymbol{D}$ are represented as the percentage of remaining mRNA after correction for the signal obtained with the mRNAs from the control cells. The inhibition of mRNA degradation by Z-VAD-fmk in JHM12 cells is not complete $(\boldsymbol{C}, \boldsymbol{D})$, because of the variability between experiments (in other experiments, full inhibition had been observed). 
Fig. 7

A
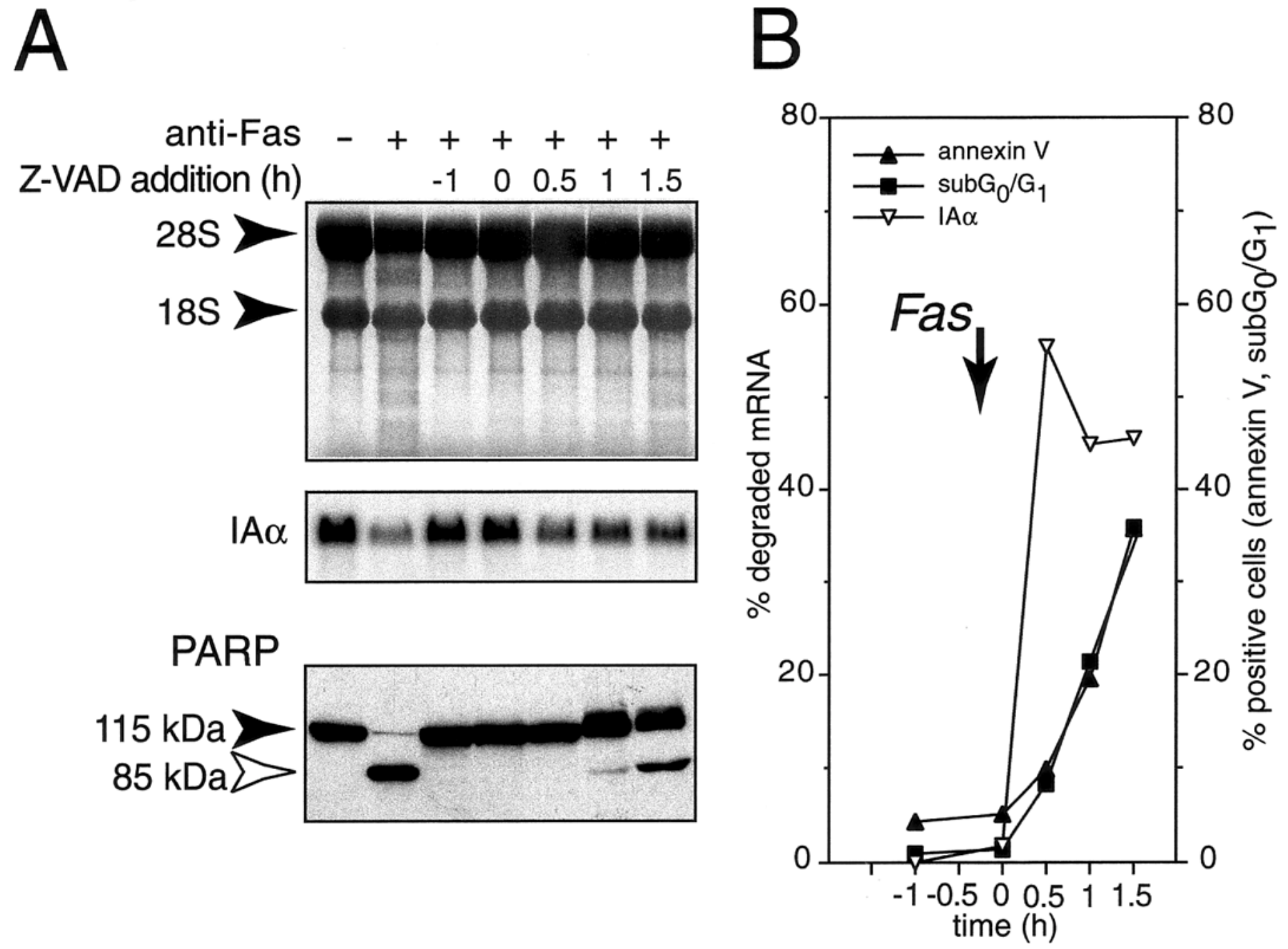

Figure 7. Kinetics of Z-VAD-fmk inhibition of apoptosis in A20 cells allowed discrimination between mRNA degradation and other apoptotic markers. The kinetic effects of Z-VAD-fmk were analyzed with A20 cells treated for $6 \mathrm{~h}$ with anti-Fas mAb, when the inhibitor was added at different times ranging from $1 \mathrm{~h}$ before to $1.5 \mathrm{~h}$ after the addition of anti-Fas antibody. Control, untreated cells had the following characteristics: $3 \%$ were annexin $\mathrm{V}$ positive, $1 \%$ were in the sub $-\mathrm{G}_{0} / \mathrm{G}_{1}$ phase of the cell cycle, and PARP processing was undetectable; anti-Fas-treated cells had the following characteristics: $73 \%$ were annexin V positive, 59\% were in the sub- $\mathrm{G}_{0} / \mathrm{G}_{1}$ phase, the vast majority of PARP was processed; and $84 \%$ of mRNA was degraded. $\boldsymbol{A}$ ) Methylene blue staining of the RNA samples, hybridization with the specific murine IA $\alpha$ mRNA, and detection of PARP processing by Western blotting. B) Quantification of annexin V-positive cells, cells in the sub- $\mathrm{G}_{0} / \mathrm{G}_{1}$ phase, and IA $\alpha$ mRNA degradation. 
Fig. 8

A
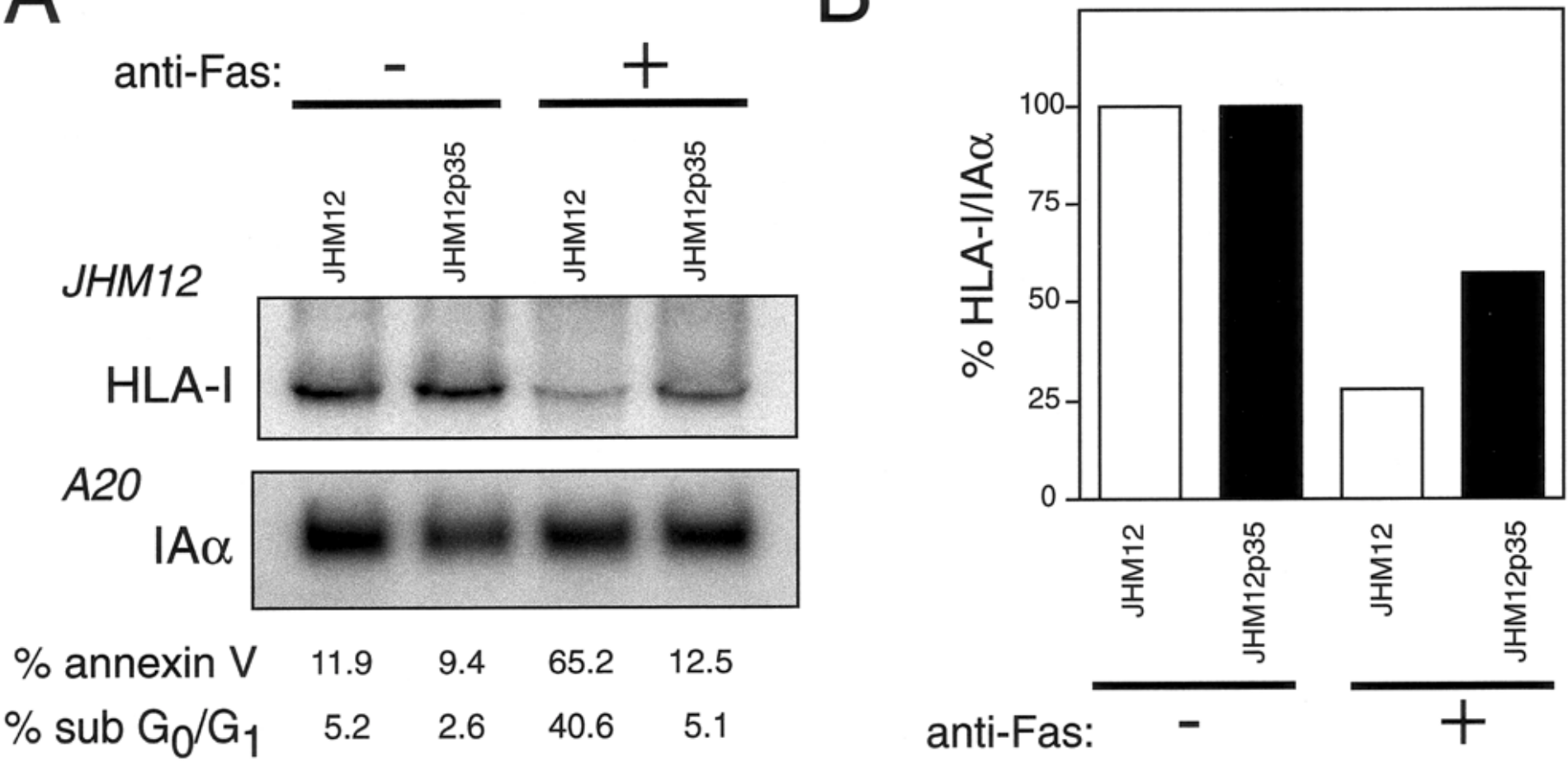

Figure 8. p35 inhibited apoptosis but did not abrogate mRNA degradation. Experiments such as those described in the legend to Fig. 6 were carried out with Jurkat JHM12 cells or Jurkat cells constitutively expressing p35, a caspase inhibitor that abrogates apoptosis induced by direct triggering of death receptors. $\boldsymbol{A}$ ) mRNA expression levels in wild-type and p35-expressing cells, before and after an 8-h treatment with anti-CD95 antibodies. Fas-treated cells were mixed with A20 control cells to demonstrate specificity of the degradation. B) Quantification of data shown in $\boldsymbol{A}$, represented as a percentage of the remaining mRNA after correction of the specific HLA-I signal for each lane with the values obtained for the control IA $\alpha$ mRNA. 
Fig. 9
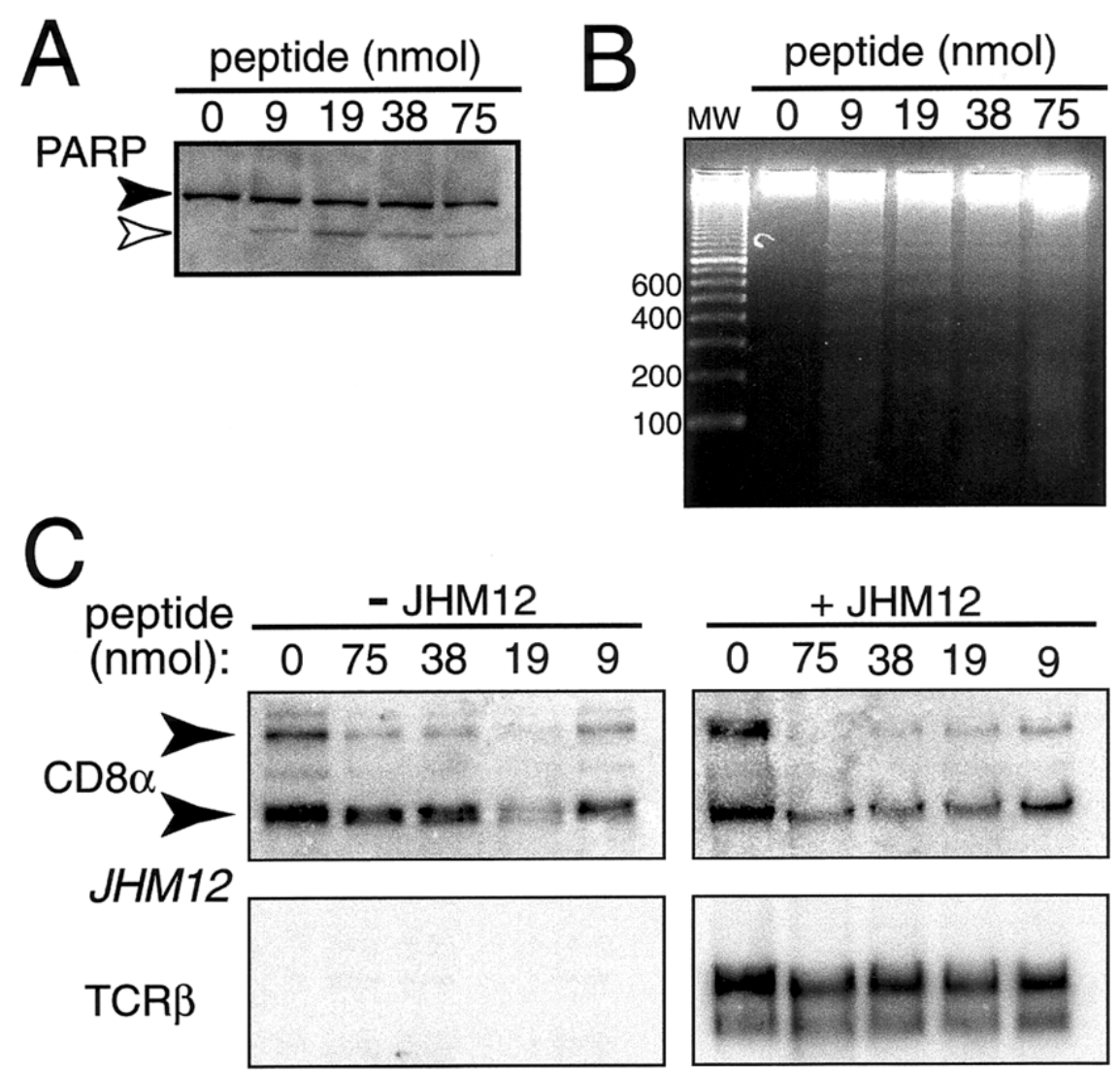

D

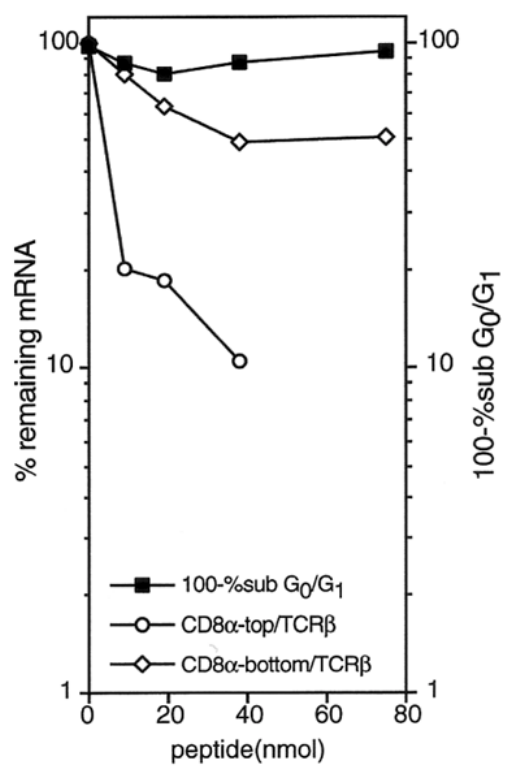

Figure 9. mRNA degradation was found to be an early step in in vivo antigen-induced thymocyte apoptosis. Representative experiment demonstrating that thymocyte apoptosis was induced by intraperitoneal injection of antigenic peptide $(9-75 \mathrm{nmol})$ in F5-TCR transgenic mice; injection of PBS served as the control. Samples were analyzed $90 \mathrm{~min}$ after injection; one animal was used for each peptide concentration. $\boldsymbol{A}$ ) PARP processing. $\boldsymbol{B}$ ) DNA fragmentation. $\boldsymbol{C}$ ) mRNA expression levels for mouse CD8 $\alpha$ and control human TCR $\beta$ in samples of thymocytes alone (-JHM12) or mixed with JHM12 cells (+JHM12). D) Quantification of the fraction of cells in the sub- $\mathrm{G}_{0} / \mathrm{G}_{1}$ phase of the cell cycle, together with the data from $C$, represented as a percentage of remaining mRNA after correction, for each lane, of the specific CD8 $\alpha$ signals with the values obtained for the control TCR $\beta$ mRNA. 